\title{
Penerapan Model Pembelajaran Think Talk Write untuk Meningkatkan Keterampilan Pemecahan Masalah
}

\section{Arif Wahyu Hidayat}

Universitas Sebelas Maret

arif.wahyuhidayat@student.uns.ac.id

\section{Article History}

received 30/4/2021

\begin{abstract}
Problem solving skill is important to make students math literate. The purpose of this research is to improve the problem solving skill in plan figure applying Think Talk Write learning model. The subject of this research were students of IV class at Sedayu Elementary School Purworejo In the 2020/2021 academic year, totaling 25 students. Classroom Action Research technique with two circle. Data collection technique are using observation, documentation, interviews, and test. Data validity test is using triangulation technique. Data Analysis technique is using Interactive Model of Miles-Huberman. The initial condition of problem solving skills is the average value class score 50,04 with $36,00 \%$ completeness. The last learning condition is 84,27 average value score and $80 \%$ of classical completeness. Based on the results, it can concluded that through application of Think Talk Write learning model can improve problem solving skills in class IV Sedayu Elementary School, Purworejo at 2020/2021 academic year.
\end{abstract}

Keywords: problem solving skills, Think Talk Write, plane figure, elementary school

\begin{abstract}
Abstrak
Keterampilan pemecahan masalah penting dikembangkan untuk literasi matematika pada peserta didik. Tujuan dari penelitian ini adalah untuk meningkatkan keterampilan pemecahan masalah pada materi bangun datar dengan menerapkan model pembelajaran Think Talk Write. Subjek penelitian ini adalah peserta didik kelas IV SD Negeri Sedayu Purworejo, Tahun Pelajaran 2020/2021 yang berjumlah 25 siswa. Teknik Penelitian Tindakan Kelas dengan dua siklus. Teknik pengumpulan data menggunakan observasi, dokumentasi, wawancara, dan tes. Uji validitas data menggunakan teknik triangulasi. Teknik Analisis Data menggunakan Model Interaktif Miles-Huberman. Kondisi awal keterampilan pemecahan masalah adalah nilai ratarata skor kelas 50,04 dengan ketuntasan $36,00 \%$. Kondisi akhir menghasilkan nilai rata-rata 84,27 dan ketuntasan klasikal $80 \%$. Berdasarkan hasil penelitian dapat disimpulkan bahwa melalui penerapan model pembelajaran Think Talk Write dapat meningkatkan kemampuan pemecahan masalah siswa kelas IV SD Sedayu Purworejo Tahun Pelajaran 2020/2021.

Kata kunci: Keterampilan pemecahan masalah, Think Talk Write, bangun datar, sekolah dasar
\end{abstract}




\section{PENDAHULUAN}

Keterampilan pemecahan masalah merupakan salah satu keterampilan yang penting dan perlu dikuasai oleh peserta didik yang terintegrasi dalam keterampilan abad 21 (Anesa Surya, 2019). Keterampilan pemecahan masalah ini termasuk tujuan pembelajaran matematika pada jenjang sekolah dasar (Shadiq, 2014). Keterampilan pemecahan masalah memegang peranan penting dalam pembelajaran matematika, karena melalui keterampilan ini dapat melatih dan mengintegrasikan konsep, dapat melatih berpikir logis, kiritis, analitis, sistematis, dan kreatif, serta dapat meningkatkan pengetahuannya tentang konsep matematika (Tambunan, 2019)(Surya, Putri, and Mukhtar, 2017)(Anesa Surya, 2019). Peserta didik dikatakan terampil dalam memecahkan masalah apabila mereka memahami langkah pemecahan masalah, merencanakan pemecahan masalah dan juga meninjau pemecahan masalah (Widiawati et al., 2020). Indikator yang dapat mengukur keterampilan pemecahan masalah menurut Polya antara lain 1) memahami masalah, 2) menyusun rencana penyelesaian, 3) melaksanakan rencana penyelesaian, dan 4) memeriksa kembali prosedur dan hasil penyelesaian (Purnamasari and Setiawan, 2019).

Penguasaan keterampilan pemecahan masalah pada umumnya masih rendah. Hal tersebut dibuktikan dengan penelitian sebelumnya yakni penelitian yang dilakukan oleh Anesa Surya (2019) dengan peserta didik yang terampil berjumlah 2 dari 32 peserta didik. Fakta di lapangan yang ditemukan di SD Negeri Sedayu, Purworejo Tahun Ajaran 2020/2021 menunjukkan bahwa peserta didik belum menguasai keterampilan pemecahan masalah yang dibuktikan dengan hasil pratindakan. Hasil pratindakan menunjukkan nilai rerata kelas 50,04 dan ketuntasan klasikalnya 36,00\%. Hal ini membuktikan bahwa keterampilan pemecahan masalah tergolong rendah dan perlu diberikan tindakan.

Rendahnya keterampilan pemecahan masalah perlu ditindak lanjuti. Penelitian yang dilakukan oleh Darma (2018) meningkatkan pemecahan masalah dengan model pembelajaran Problem Based Learning, sementara penelitian yang dilakukan oleh Rostika \& Junita (2017) menyatakan bahwa pemecahan masalah pada peserta didik dapat ditingkatkan dengan menggunakan model pembelajaran Diskursus Multy Representation (DMR). Penelitian yang dilakukan oleh Sopiany \& AS (2016) meningkatkan kemampuan pemecahan masalah dengan strategi pembelajaran Think Talk Write. Ketiga penelitian yang telah disebutkan membuktikan bahwa dengan menerapkan model pembelajaran inovatif dapat meningkatkan pemecahan masalah matematika pada peserta didik. Berdasarkan hal ini, peneliti menerapkan model pembelajaran inovatif dalam upaya meningkatkan keterampilan pemecahan masalah materi bangun datar. Model pembelajaran yang akan diterapkan adalah model pembelajaran Think Talk Write (TTW). Model pembelajaran Think Talk Write (TTW) menurut Isrok'atun \& Rosmala (2018) berlandaskan kontruktivisme yang diterapkan melalui kegiatan berpikir, berbicara, dan menulis. Model Think Talk Write (TTW) merupakan salah satu model pembelajaran koooperatif yang memiliki tujuan yaitu melatih keterampilan peserta didik dalam menulis serta mengembangkan kreativitas peserta didik dalam berpikir kritis, berkarya, berkomunikasi dengan aktif melalui sarana diskusi kelompok, dan juga mengembangkan kreativitas peserta didik dalam menuliskan hasil diskusi kelompok (Ngalimun, 2017). Model Think Talk Write (TTW) dapat membantu peserta didik dalam mengembangkan keterampilan pemecahan masalah karena melalui model ini peserta didik diperkenankan untuk mencari ide-ide melalui diskusi kelompok. Silver dan Smith (Huda, 2013) menyatakan bahwa guru juga berperan dalam usaha mengefektifkan penggunaan model Think Talk Write (TTW) yaitu dengan cara menyediakan tugas yang memungkinkan peserta didik terlibat secara aktif dalam berfikir kreatif, berkomunikasi secara aktif dalam diskusi serta dapat mengemukakan ide-ide secara lisan maupun tertulis. 
Berdasarkan uraian di atas maka rumusan masalah dari penelitian ini adalah Apakah penerapan model pembelajaran Think Talk Write (TTW) dapat meningkatkan keterampilan pemecahan masalah pada soal cerita bangun datar peserta didik Kelas IV SD Negeri Sedayu tahun ajaran 2020/2021? Tujuan penelitian ini adalah untuk meningkatkan keterampilan pemecahan masalah pada soal cerita bangun datar peserta didik Kelas IV SD Negeri Sedayu tahun ajaran 2020/2021. Manfaat setelah dilakukan penelitian ini yakni dapat menjadi relevansi untuk meningkatkan keterampilan pemecahan masalah melalui model pembelajaran inovatif.

\section{METODE}

Penelitian ini dilaksanakan pada peserta didik kelas IV SD Negeri Sedayu, Purworejo tahun ajaran 2020/2021 dengan jumlah 25 peserta didik yang tidak adanya peserta didik berkebutuhan khusus. Penelitian ini dilaksanakan selama 6 bulan yakni mulai Januari sampai Juni 2021. Pendekatan yang digunakan adalah pendekatan kualitatis dengan jenis Penelitian Tindakan Kelas (PTK). Data yang digunakan adalah data kuantitatif berupa nilai keterampila pemecahan masalah, skor aktivitas peserta didik dalam pembelajaran, dan skor kinerja guru dalam pembelajaran. Sementara data kualitatif berupa wawancara dan hasil dokumentasi. Sumber data terdiri dari tiga yakni sumber data informan berupa guru, sumber data penerima tindakan berupa peserta didik, dan dokumen seperti silabus, RPP, hasil wawancara, foto dan video pembelajaran, dan hasil tes keterampilan pemecahan masalah. Teknik pengumpulan data berupa observasi dengan alat pengumpulan data lembar observasi, wawancara dengan alat pengumpulan data lembar wawancara, tes dengan alat pengumpulan data berupa soal, serta dokumentasi dengan alat pengumpulan data berupa silabus, RPP, hasil tes, foto, dan video pembelajaran. Uji validitas dengan menggunakan triangulasi Teknik. Teknik analisis data dengan menggunakan model Miles dan Huberman.

\section{HASIL DAN PEMBAHASAN}

Sebelum dilaksanakan tindakan, peneliti melakukan pratindakan dengan tes keterampilan pemecahan masalah. Hasil analisis peneliti dituangkan dalam grafik berikut:

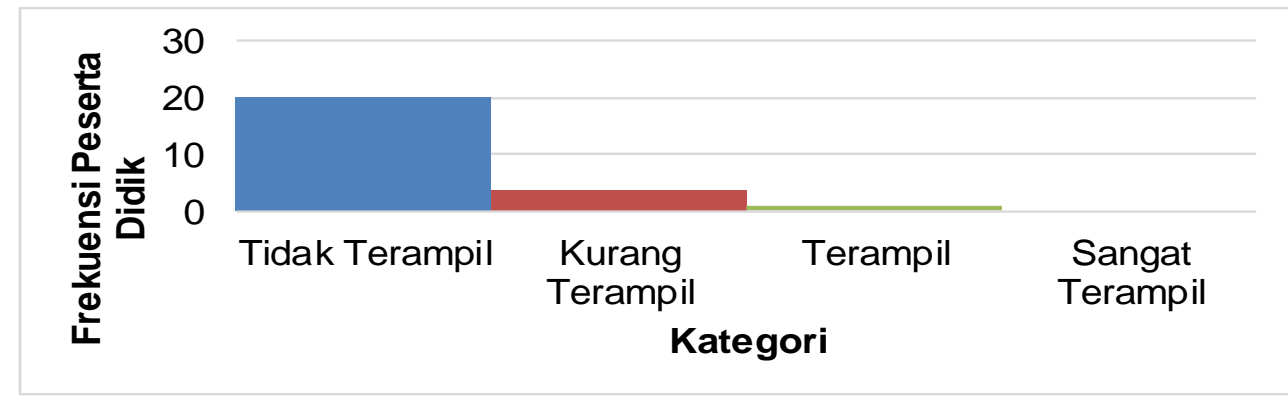

Gambar 1. Grafik Hasil Konversi Keterampilan Pemecahan Masalah Pratindakan

Berdasarkan grafik di atas, diketahui frekuensi terbesar terdapat pada kategori tidak terampil sebesar $80 \%$ yang membuktikan bahwa berdasarkan kondisi kelas, peserta didik yang memerlukan penanganan untuk ditingkatkan keterampilan pemecahan masalahnya tergolong tinggi. Sementara ketuntasan klasikal pratindakan sebesar $36,00 \%$ dan rerata nilai pratindakan sebesar 50,04. Hasil ini sesuai dengan penelitian yang dilakukan oleh Anesa Surya (2019) yang telah membuktikan bahwa keterampilan pemecahan masalah pada peserta didik masih rendah dan didukung oleh hasil survei oleh TIMSS 2007 dan PISA yang membuktikan kualitas pembelajaran di Indonesia tergolong rendah (Darma, 2018). 
Rendahnya keterampilan pemecahan masalah pada peserta didik perlu ditindak lanjuti. Model pembelajaran Think Talk Write diterapkan untuk meningkatkan keterampilan pemecahan masalah pada peserta didik. Pelaksanaan dimulai dengan siklus 1 . Hasil analisis siklus 1 adalah sebagai berikut:

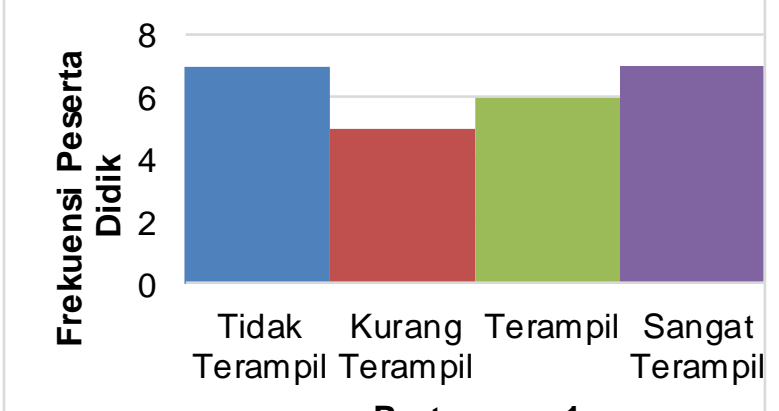

Pertemuan 1

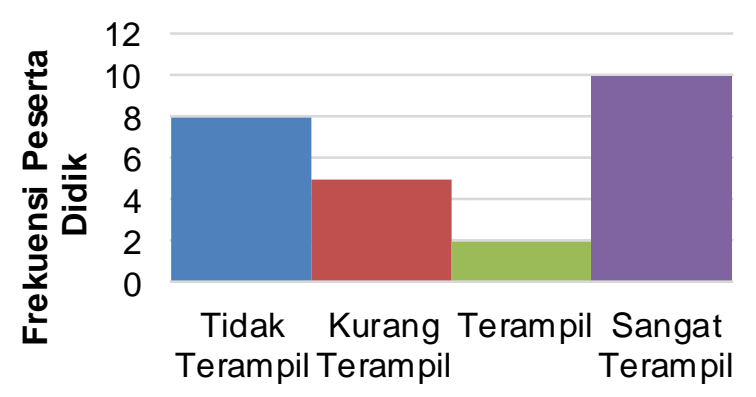

Pertemuan 2

\section{Gambar 2. Hasil Konversi Keterampilan Pemecahan Masalah Siklus I}

Berdasarkan hasil analisis di atas, pada pertemuan pertama menunjukkan bahwa peserta didik yang tergolong tidak terampil masih tinggi, sementara pada pertemuan kedua sudah mengalami peningkatan dan frekuensinya tergolong meningkat. Hasil penelitian siklus I menunjukkan terjadi peningkatan keterampilan pemecahan masalah. Peningkatan tersebut dibuktikan dengan hasil rerata skor pertemuan 1 yakni 75,38 dan pertemuan kedua 77,96 . Bukti lainnya adalah dari ketuntasan klasikal, pertemuan pertama sebesar $60,00 \%$ dan $64,00 \%$.

Penelitian dilanjutkan pada siklus kedua. Hasil analisis disajikan dalam bentuk grafik sebagai berikut:

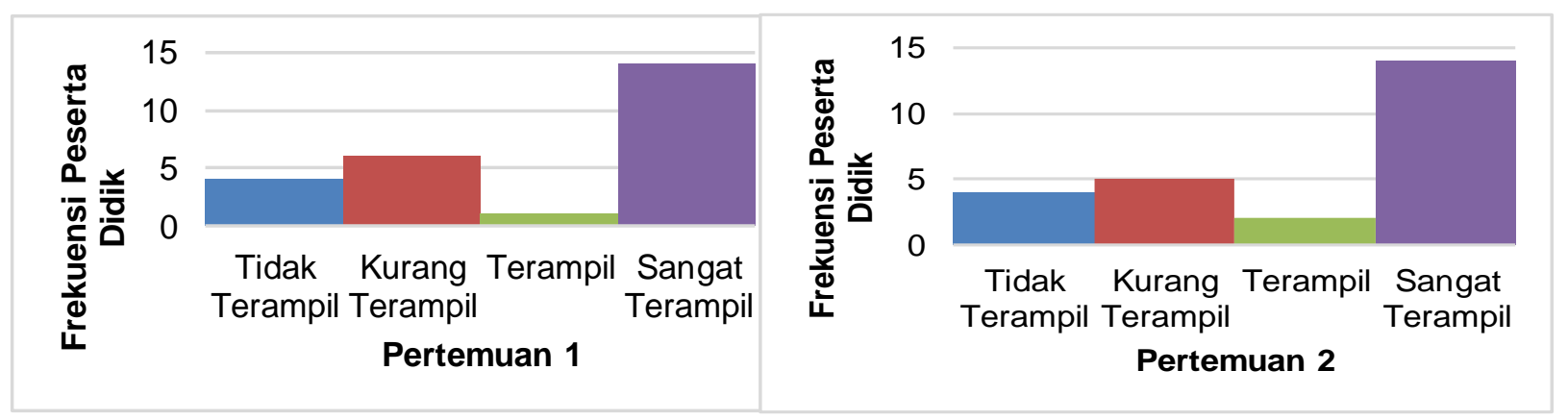

Gambar 2. Hasil Konversi Keterampilan Pemecahan Masalah Siklus II

Berdasarkan hasil analisis di atas, pada pertemuan pertama maupun kedua frekuensi terbesar yakni peserta didik dengan golongan sangat terampil. Bukti lainnya adalah persentase ketuntasan klasikal. Siklus kedua pertemuan pertama persentas ketuntasan klasikalnya adalah $76,00 \%$ dan pertemuan kedua adalah $80,00 \%$. Hasil ini menyatakan bahwa penelitian ini sudah mencapai indikator kinerja penelitian yakni sebesar $75 \%$. Bukti laninnya adalah hasil rerata skor yakni 85,33 untuk pertemuan pertama dan 84,27 untuk pertemuan kedua. Hasil ini menunjukkan bahwa model pembelajaran Think Talk Write dapat meningkatkan keterampilan pemecahan masalah.

Keterampilan pemecahan masalah peserta didik secara klasikal dapat meningkat melalui indikator yang ada. Indikator pertama yaitu memahami uraian permasalahan, mengalami peningkatan dari $80 \%$ menjadi $100 \%$. Menyusun rencana penyelesaian mengalami peningkatan dari $48 \%$ menjadi $96 \%$. Tahap melaksanakan recana 
penyelesaian mengalami peningkatan dari $8 \%$ menjadi $76 \%$. Indikator menyimpulkan mengalami peningkatan dari $28 \%$ menjadi $96 \%$. Secara keseluruhan persentase ketuntasan klasikal juga mengalami peningkatan dari 36\% menjadi $80 \%$. Hal tersebut sejalan dengan penelitian yang dilakukan oleh Anesa Surya (2019) bahwa keterampilan pemecahan masalah dapat ditingkatkan melalui model pembelajaran inovatif.

Melalui model pembelajaran Think Talk Write (TTW), peserta didik dapat berpikir, berbicara, dan menuangkan ide. Pelaksanaan model ini berjalan dengan lancar. Terdapat peningkatan kinerja guru dan aktivitas peserta didik. Hasil siklus I pertemuan pertama dan kedua mendapatkan skor rata-rata 2,7 dalam kategori baik. Peningkatan terjadi pada siklus II. Hasil siklus II pertemuan pertama dan kedua mendapat skor 3,12 dalam kategori sangat baik. Aktivitas peserta didik juga mengalami peningkatan. Hasil siklus I pertemuan pertama dan kedua mendapatkan skor rata-rata 2,58. Hasil siklus II pertemuan pertama dan kedua mendapat skor 3 dalam kategori baik. Bukti tersebut menjadi salah satu penyebab meningkatnya keterampilan pemecahan masalah pada peserta didik. Selain itu juga sesuai dengan penelitian yang dilakukan oleh Sopiany \& AS (2016) dalam JPPM menyatakan bahwa strategi pembelajaran Think Talk Write lebih efektif dalam meningkatkan kemampuan pemecahan masalah pada matematika.

Peningkatan keterampilan pemecahan masalah peserta didik karena model pembelajaran Think Talk Write (TTW) berorientasi pada keaktifan peserta didik dalam menganalisis suatu permasalahan pemecahan masalah. Peserta didik dibimbing untuk memecahkan masalah, pemecahan masalah dengan menganalisis permasalahan tersebut dengan beberapa cara yang sesuai sehingga peserta didik dapat menyimpulkan hasil akhir dari analisis masalah pemecahan masalah serta diharapkan dapat mengimplementasikan dalam kehidupan sehari-hari. Hal tersebut sejalan dengan pendapat Isrok'atun \& Rosmala (2018) yang menyatakan bahwa dengan model ini peserta didik dibimbing menganalisis suatu permasalahan sehingga dapat menyimpulkan hasil pemecahan masalah.

Selain keterampilan pemecahan masalah meningkat, aktivitas peserta didik dan kinerja juga mengalami peningkatan. Hal tersebut sesuai dapat dilihat dari hasil observasi aktivitas peserta didik dan kinerja guru. Peningkatan aktvitas peserta didik tersebut sesuai dengan pendapat Shoimin (2016) yang menyatakan bahwa peserta didik berpartisipasi aktif dalam pembelajaran dan sering menuangkan idenya.

Meskipun terjadi peningkatan pada aktivitas peserta didik, namun ditemukan beberapa kendala. Kendalanya adalah sebagian peserta didik menggantungkan pekerjaannya pada kelompok. Kendala ini juga ditemukan oleh Palupi, Suyitno, dan Prabowo (2016), dalam penelitian pertemuan pertamanya kerja kelompok belum terjalin karena sebagian besar anggota kelompok hanya bergantung pada anggota kelompok yang lebih pintar. Kendala tersebut diatasi dengan guru lebih mengawasi aktivitas peserta didik, dibuatkan ketua dan wakil ketua kelompok yang menilai kinerja anggotanya, dan guru memberikan lembar kerja peserta didik (LKPD) secara individu, namun mereka mengerjakannya masih dalam situasi kelompok.

Setelah siklus II selesai, dilaksanakan wawancara terhadap guru kelas IV mengenai penerapan model pembelajaran Think Talk Write (TTW) dalam pembelajaran keterampilan pemecahan masalah. Guru kelas IV menyatakan bahwa dengan menggunakan model pembelajaran ini peserta didik dapat merespons pembelajaran, dapat meningkatkan keaktifan peserta didik dalam pembelajaran, membantu peserta didik dalam memecahkan masalah, dan menggunakan model ini materi yang disampaikan akan tertanam.

\section{SIMPULAN}


Berdasarkan hasil penelitian tindakan kelas yang telah dilaksanakan selama dua siklus dalam meningkatkan keterampilan pemecahan masalah dengan menggunakan model pembelajaran Think Talk Write, dapat disimpulkan bahwa model pembelajaran Think Talk Write (TTW) dapat meningkatkan keterampilan pemecahan masalah pada peserta didik kelas IV SD Negeri Sedayu tahun ajaran 2020/2021. Hasil penelitian secara teoritis dapat memberikan implikasi yaitu pengetahuan dan referensi pada penelitian yang sejenis. Penelitian ini juga memberikan implikasi praktis berupa peningkatan keterampilan pemecahan masalah materi bangun datar setelah diterapkannya model pembelajaran Think Talk Write (TTW).

\section{DAFTAR PUSTAKA}

Anesa Surya, Meti Widiawati, Siti Istiyati. 2019. "Keterampilan Pemecahan Masalah Matematis Pada Peserta Didik Kelas V Sekolah Dasar." Jurnal Pendidikan Dasar 7(1):1-6. doi: 10.20961/jpd.v7i1.29300.

Darma, I. K. 2018. "Improving Mathematical Problem Solving Ability through ProblemBased Learning and Authentic Assessment for the Students of Bali State Polytechnic." Journal of Physics: Conference Series 953(1). doi: 10.1088/17426596/953/1/012099.

Huda, Miftahul. 2013. Model-Model Pengajaran Dan Pembelajaran. Malang: Pustaka Pelajar.

Isrok'atun, and Amelia Rosmala. 2018. Model-Model Pembelajaran Matematika. Bandung: Bumi Aksara.

Ngalimun. 2017. Strategi Pembelajara Dilengkapi Dengan 65 Model Pembelajaran. Palangka Raya: Dua Satria Offet.

Palupi, H. R., H. Suyitno, and A. Prabowo. 2016. "Keefektifan Model Pembelajaran Means Ends Analysis Pada Kemampuan Pemecahan Masalah Siswa Materi Segiempat." Unnes Journal of Mathematics Education Vol. 5 (2)(ISSN 240-5840).

Purnamasari, Irma, and Wahyu Setiawan. 2019. "Analisis Kemampuan Pemecahan Masalah Matematis Siswa SMP Pada Materi SPLDV Ditinjau Dari Kemampuan Awal Matematika." Journal of Medives: Journal of Mathematics Education IKIP Veteran Semarang 3(2):207. doi: 10.31331/medivesveteran.v3i2.771.

Rostika, Deti, and Herni Junita. 2017. "Peningkatan Kemampuan Pemecahan Masalah Siswa Sd Dalam Pembelajaran Matematika Dengan Model Diskursus Multy Representation (Dmr)." EduHumaniora / Jurnal Pendidikan Dasar Kampus Cibiru 9(1):35. doi: 10.17509/eh.v9i1.6176.

Shadiq, Fadjar. 2014. Pembelajaran Matematika Cara Meningkatkan Kemampuan Berpikir Siswa. Yogyakarta: Graha Imu.

Shoimin. 2016. 68 Model Pembelajaran Inovatif Dalam Kurikulum 2013. Yogyakarta: Ar-Ruzz Media.

Sopiany, Hanifah Nurus, and Ipah Syarifatul Hijjah AS. 2016. "Penggunaan Strategi Ttw(Think-Talk-Write) dengan Pendekatan Kontekstual dalam Meningkatkan Kemampuan Pemecahan Masalah dan Disposisi Matematis Siswa MTSN Rawamerta Karawang." Jppm 9(2):268-76.

Surya, Edy, Feria Andriana Putri, and Mukhtar. 2017. "Improving Mathematical Problem-Solving Ability and Self-Confidence of High School Students through Contextual Learning Model." Journal on Mathematics Education 8(1):85-94. doi: 10.22342/jme.8.1.3324.85-94.

Tambunan, Hardi. 2019. "The Effectiveness of the Problem Solving Strategy and the Scientific Approach to Students' Mathematical Capabilities in High Order Thinking Skills." International Electronic Journal of Mathematics Education 14(2):293-302. doi: $10.29333 /$ iejme/5715.

Widiawati, Meti, Anesa Surya, Siti Istiyati, and Sukarno. 2020. "Error Analysis of FifthGrade Students of Elementary School in Geometry Problem Solving Based on 
Volume 9 Nomor 1 Tahun 2021

Newman's Procedure." Universal Journal of Educational Research 8(5):1676-82. doi: 10.13189/ujer.2020.080503. 